\title{
Effects of small rivers on chemical properties of sediment and diets for primary consumers in estuarine tidal flats
}

\author{
Takashi Sakamaki*, John S. Richardson \\ Department of Forest Sciences, University of British Columbia, 3041-2424 Main Mall, Vancouver, \\ British Columbia V6T 1Z4, Canada
}

\begin{abstract}
We compared effects of particulate organic matter (POM) transported from small rivers $\left(\mathrm{POM}_{\mathrm{R}}\right)$ on chemical properties of sediment and diets of primary consumers in 3 estuarine tidal flats with different watershed characteristics in southwestern British Columbia, Canada. The source rivers (0.1 to $1.9 \mathrm{~m}^{3} \mathrm{~s}^{-1}$, annual mean) flowed through forested and urbanized areas (FR) or through agricultural areas (AG1 and AG2). The C:N ratio of $\mathrm{POM}_{\mathrm{R}}$ was significantly higher in FR (8.6 to 10.1) than in AG1 and AG2 (6.7 to 7.0). The chlorophyll a concentration of river water was significantly lower in FR $\left(0.4 \mu \mathrm{g} \mathrm{l}^{-1}\right)$ than in AG1 and AG2 (9.4 to $\left.10.3 \mu \mathrm{g}^{-1}\right)$. In the tidal flat of FR, organic matter of sediment (SPOM) had relatively higher C:N ratios (FR, 17.9; AG1, 9.6 and AG2, 8.2), suggesting the accumulation of terrestrial organic matter. Mixing model (IsoSource) calculations based on stable isotope measurements showed that in the tidal flat of FR, $\mathrm{POM}_{\mathrm{R}}$ was dominant in $\operatorname{SPOM}(\sim 70 \%)$, also suggesting $\mathrm{POM}_{\mathrm{R}}$ was an important food source for some primary consumers (37 to $48 \%$ ) as were benthic microalgae ( 35 to $45 \%$ ). In AG1 and $\mathrm{AG} 2, \mathrm{POM}_{\mathrm{R}}$ did not dominate SPOM, and there was no evidence of significant incorporation of $\mathrm{POM}_{\mathrm{R}}$ into macrobenthos diets. In the present study, $\mathrm{POM}_{\mathrm{R}}$ from the watershed with substantial forest areas appeared to be more influential on the chemical properties of sediment and macrobenthos diets in the tidal flat. This could be attributed to the low degradability and long retention of $\mathrm{POM}_{\mathrm{R}}$ in the tidal flat sediments.
\end{abstract}

KEY WORDS: Particulate organic matter · River · Forest · Intertidal flat · Estuary · Stable isotope · Ratio of carbon to nitrogen

\section{INTRODUCTION}

Estuarine tidal flats are situated at the transition from land to the ocean system and are expected to receive materials transported through rivers, such as sediment, organic matter and nutrients (e.g. Wipfli et al. 2007). Watershed characteristics (e.g. land use, hydrology and geological features) greatly affect the quality and quantity of such material (e.g. Johnson et al. 1997, Otero et al. 2000, Noe \& Hupp 2005, Sakamaki \& Richardson 2008). Estuarine ecosystems are considered to be highly productive and biologically diverse and play an important role as nurseries for various organisms including salmonid fish (e.g. Levings et al. 1991, Thorpe 1994, Costanza et al. 1997, Bottom et al. 2005). To achieve sustainable watershed management consistent with conserving such valuable estuarine ecosystems, better understanding of the linkage between riverine and estuarine systems is required.

Previous studies have shown that particulate organic matter $(\mathrm{POM})$ transported through rivers $\left(\mathrm{POM}_{\mathrm{R}}\right)$ is one significant component of suspended and deposited organic matter in estuaries (e.g. Thornton \& McManus 1994, Chanton \& Lewis 2002, Ogrinc et al. 2005). However, $\mathrm{POM}_{R}$ is potentially highly variable in its quality, since it can consist of organic matter from various sources, e.g. terrestrial, aquatic and human, and the mixture of those sources could strongly 
depend on watershed conditions. In general, terrestrially produced organic matter, such as wood, leaves and other plant debris, is less degradable than aquatically produced organic matter, such as algae (Enríquez et al. 1993). This suggests that the origin and chemical properties of $\mathrm{POM}_{\mathrm{R}}$ could affect its consumption and abundance in sediments of estuarine tidal flats.

Some studies based on stable isotope methods have demonstrated that $\mathrm{POM}_{\mathrm{R}}$ was the primary food source for estuarine macrobenthos (e.g. Darnaude 2005, Kasai \& Nakata 2005). However, $\mathrm{POM}_{\mathrm{R}}$ is not always an important food source for macrobenthos even in estuarine tidal flats where $\mathrm{POM}_{R}$ dominates POM in the water column and sediment (Yokoyama \& Ishihi 2003). POM from offshore $\left(\mathrm{POM}_{\mathrm{O}}\right)$, dominated by phytoplankton, and benthic microalgae also have been reported to be disproportionately assimilated by tidal flat macrobenthos (e.g. Lee 2000, Kang et al. 2003, Yokoyama \& Ishihi 2003, Kasai et al. 2004, Yokoyama et al. 2005). To date, the necessary conditions for contributions of $\mathrm{POM}_{\mathrm{R}}$ to tidal flat macrobenthos have not been clear. In particular, previous studies on estuarine tidal flat food webs did not describe or consider the effects of $\mathrm{POM}_{R}$ quality. In the present study, we assumed that variation in $\mathrm{POM}_{\mathrm{R}}$ quality could affect the contribution of $\mathrm{POM}_{\mathrm{R}}$ to diets of tidal flat macrobenthos and alter the relative importance of each potential food source.

From a stoichiometric perspective, organic matter with higher nitrogen content is usually easily degradable and often readily assimilated by organisms (Tenore 1977, Tenore \& Hanson 1980, Enríquez et al. 1993, Bowen et al. 1995). These facts enable us to assume that the ratio of carbon to nitrogen $(\mathrm{C}: \mathrm{N})$ of $\mathrm{POM}_{\mathrm{R}}$ is a significant predictor for its residence time and incorporation into food webs in estuarine ecosystems. However, these 2 factors, residence time and biological assimilability, are likely negatively related. For example, if $\mathrm{POM}_{\mathrm{R}}$ has a low $\mathrm{C}: \mathrm{N}$, it has the potential to be a preferred food source of high quality but may be rapidly depleted in the tidal flat due to its high degradability. Hence, consequential effects of variation in $\mathrm{C}: \mathrm{N}$ of $\mathrm{POM}_{\mathrm{R}}$ on estuarine food webs are complicated and hard to predict based on current knowledge.

In the present study, we investigated 3 estuarine tidal flat ecosystems linking to rivers flowing mainly through forested and urbanized areas (FR) or through agricultural areas (AG1 and AG2). We assumed that in FR the tidal flat received less degradable and less nutritious $\mathrm{POM}_{\mathrm{R}}$ originating from forests, whereas in AG1 and AG2 the tidal flats received more degradable and more nutritious $\mathrm{POM}_{\mathrm{R}}$ originating from aquatically produced algae. In each tidal flat we determined the contributions of $\mathrm{POM}_{\mathrm{R}}$ to $\mathrm{POM}$ of the tidal flat sediments (SPOM) and macrobenthos diets. Then, based on the comparison of those 3 estuarine tidal flats, we addressed the question: Is $\mathrm{POM}_{\mathrm{R}}$ quality an important factor controlling chemical properties and food webs of the estuarine tidal flats?

\section{MATERIALS AND METHODS}

Study sites. The 3 estuaries that we studied are located near Vancouver, British Columbia, Canada $\left(49^{\circ} 03^{\prime}\right.$ to $17^{\prime} \mathrm{N}, 122^{\circ} 50^{\prime}$ to $55^{\prime} \mathrm{W}$ ) (Fig. 1). The estuary of $F R$ receives 2 small rivers $\left(\mathrm{R}_{\mathrm{FR} 1}\right.$ and $\left.\mathrm{R}_{\mathrm{FR} 2}\right)$, which discharge at about 0.3 and $0.1 \mathrm{~m}^{3} \mathrm{~s}^{-1}$ (annual mean), respectively. Both rivers arise from forested, mountainous areas and flow through urbanized areas in their lower reaches. $\mathrm{R}_{\mathrm{FR} 1}$ has riparian forest buffers along the river even in the urbanized areas. $R_{F R 2}$ lacks riparian forest buffers along its urbanized lower reach. The rivers flowing into the estuaries of AG1 and AG2 $\left(\mathrm{R}_{\mathrm{AG}} 1\right.$ and $\mathrm{R}_{\mathrm{AG} 2}$ ) discharge at 1.9 and $0.1 \mathrm{~m}^{3} \mathrm{~s}^{-1}$, respectively. Both $\mathrm{R}_{\mathrm{AG} 1}$ and $\mathrm{R}_{\mathrm{AG} 2}$ originate from low-gradient areas of the Fraser River delta and flow mainly through agricultural land-use areas. Both rivers mostly lack riparian forest buffers. In each of the estuarine tidal flats, 4 sampling stations were established within the intertidal zone along the river channel and marked with wooden stakes (Fig. 1). In the present study, we refer to the 4 stations of $F R$ as $F_{a}, F_{b}, F_{c}$ and $F R_{d}$. Likewise, the stations of AG1 and AG2 were named AG1 through $\mathrm{AG}_{\mathrm{d}}$ and $\mathrm{AG} 2_{\mathrm{a}}$ through $\mathrm{AG} 2_{\mathrm{d}}$, respectively. In all the studied estuaries, the maximal tidal amplitude is about $5 \mathrm{~m}$. The bed elevations of the tidal flats were estimated to range from -1.1 to $-0.3 \mathrm{~m}$ in $\mathrm{FR}$, from -0.7 to $-0.6 \mathrm{~m}$ in AG1 and from -0.7 to $0.2 \mathrm{~m}$ in AG2 (deviations from mean water levels in 2004 to 2005). In order to focus on effects of $\mathrm{POM}_{R}$ quality, the present study design attempted to minimise differences in physical environments among the 3 estuaries. Specifically, the estuarine tidal flats selected for the present study were similar in tidal amplitudes, bed elevations and relatively small river discharge. However, coastline configurations at larger spatial scales were not controllable: the entire study area of FR is in the inner part of the inlet, whereas most sampling stations in AG1 and AG2 face the Strait of Georgia.

In the estuary of FR, macroalgae or seagrass was not observed throughout the study period. In the subtidal areas of AG1 and AG2, there was a cover of Zostera marina, and its detrital leaves were occasionally found sparsely deposited on the sediments around the stations. In the intertidal areas around some of the stations of AG1 and AG2, patches of Zostera japonica were sparsely distributed. All the stations were set in completely non-vegetated, intertidal, soft-bottom areas. 

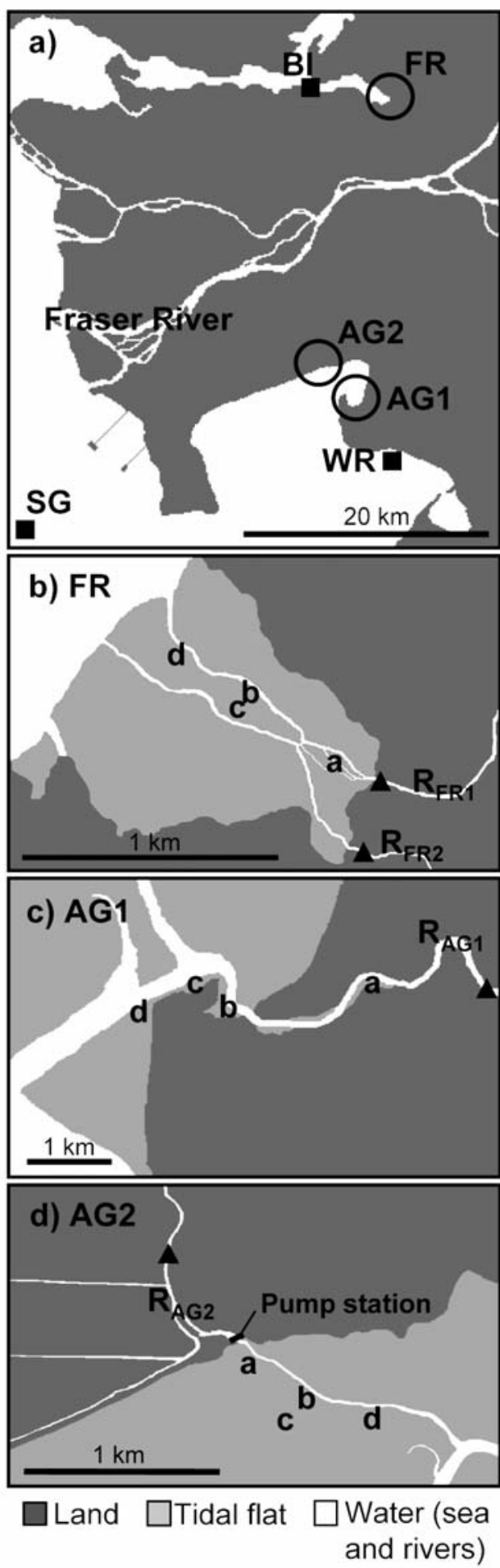

Fig. 1. (a) Locations of the 3 study estuaries (O) in the Greater Vancouver area, British Columbia, (b) FR, (c) AG1 and (d) AG2. In (a) black squares indicate sampling stations for offshore water (BI, Burrard Inlet; SG, the Strait of Georgia; WR, the White Rock beach). In (b) through (d) the small letters, a through d, show sampling stations for sediment and macrobenthos in the intertidal flats. $\mathrm{R}_{\mathrm{FR} 1}, \mathrm{R}_{\mathrm{FR} 2}, \mathrm{R}_{\mathrm{AG} 1}$ and $\mathrm{R}_{\mathrm{AG} 2}$ indicate the rivers discharging into the studied estuaries and

black triangles show sampling stations for river water
Field sampling and sample processing. Three sediment cores were collected seasonally (July and October 2004, February and May 2005) at every sampling station. In the laboratory, the 0 to $1 \mathrm{~cm}$ layer of the sediment cores was cut, and subsamples were collected and preserved in a freezer for further analyses. C and $\mathrm{N}$ stable isotopes, $\mathrm{C}$ and $\mathrm{N}$ contents, chlorophyll a (chl a) and phaeophytin a (phaeo a) contents of the sediment samples were analysed for all the 12 tidal flat stations in July 2004 and for the $4 \mathrm{FR}_{\mathrm{b}}, \mathrm{AG}_{\mathrm{a}}, \mathrm{AG}_{\mathrm{c}}$ and $\mathrm{AG} 2_{\mathrm{b}}$ stations in October 2004, February 2005 and May 2005. In July 2004, an additional sediment core was collected at every tidal flat station to determine mud content $(<63 \mu \mathrm{m})$ and grain size distributions of SPOM. Surface sediment ( 0 to $1 \mathrm{~cm}$ ) of the cores was sifted through 4000, 1000, 750, 500, 250, 125 and $63 \mu \mathrm{m}$ sieves, and each size fraction was separately analysed for organic matter (dry mass loss by ignition) to determine size distributions of SPOM. In addition, macrobenthos were collected at all the 12 tidal flat stations in July 2004 and at the $4 \mathrm{FR}_{\mathrm{b}}, \mathrm{AG}_{\mathrm{a}}, \mathrm{AG}_{\mathrm{c}}$ and $\mathrm{AG} 2_{\mathrm{b}}$ stations in October 2004, February 2005 and May 2005 by sifting tidal flat sediment through a $1 \mathrm{~mm}$ sieve. The collected macrobenthos were identified, sorted by species and frozen until $\mathrm{C}$ and $\mathrm{N}$ stable isotope analyses. At each station on each sampling occasion, 3 replicate individuals were analysed for each macrobenthos species occurring, and then the results were averaged.

To examine potential POM sources for the tidal flats, $\mathrm{POM}_{\mathrm{R}}, \mathrm{POM}_{\mathrm{O}}$ and benthic microalgae were collected. In each site, downstream freshwater was sampled for $\mathrm{POM}_{\mathrm{R}}$ monthly from July 2004 to September 2005 (Fig. 1). Offshore surface seawater ( $<50 \mathrm{~cm}$ depth) was collected for $\mathrm{POM}_{\mathrm{O}}$ in August 2004, February 2005 and October 2005. The offshore water for FR was collected at a point in Burrard Inlet (BI) $\sim 6 \mathrm{~km}$ from the estuary. The offshore water samples for AG1 and AG2 were collected at a point in the Strait of Georgia (SG) ca. 30 $\mathrm{km}$ from the estuaries in August 2004 and February 2005 and at a pier at White Rock Beach (WR) ca. $10 \mathrm{~km}$ from the estuaries in October 2005. The water samples were screened through a $1 \mathrm{~mm}$ sieve to remove coarse particles and filtered with precombusted Whatman GF/F glass fiber filters. These filter samples were preserved in a freezer for $\mathrm{C}$ and $\mathrm{N}$ stable isotopes, $\mathrm{C}$ and $\mathrm{N}$ contents and chl a analyses. In addition, the river water samples of every 2 mo were analysed for dissolved inorganic nutrients and organic carbon after filtration through $0.45 \mu \mathrm{m}$ membrane filters. Benthic microalgae were collected using the following procedure, which was slightly modified from the method established by Riera \& Richard (1996). The surface sediment $(\sim 3 \mathrm{~mm})$ was scraped by a scoop at every sampling station in the tidal flats in August 2004, and May and October 2005. In the laboratory, the sediment was 
spread in 1 to $2 \mathrm{~cm}$ thickness on a plastic plate, left for $1 \mathrm{~h}$ under lights, covered with pre-combusted (2 h at $550^{\circ} \mathrm{C}$ ) sand (>250 um) of $\sim 5 \mathrm{~mm}$ thickness and left for $2 \mathrm{~h}$ under lights again. Then the surface layer of the sand ( 3 $\mathrm{mm})$ was scraped, dispersed in filtered seawater, screened through a $63 \mu \mathrm{m}$ sieve and filtered through pre-combusted Whatman GF/F filters to concentrate benthic microalgae. Concentrated benthic diatoms from this procedure were checked by microscopic observations. Furthermore, drifted fresh leaves of the seagrass Zostera marina and macroalgae Ulva sp. were collected in the tidal flats of AG1 and AG2 in July to August 2004.

Chemical analyses. In preparation for analyses of $\mathrm{C}$ and $\mathrm{N}$ stable isotopes and $\mathrm{C}$ and $\mathrm{N}$ contents, the macrobenthos tissue, sediment, POM, benthic microalgae, seagrass and macroalgae samples were treated with $10 \% \mathrm{HCl}$, rinsed with distilled water and dried at $60^{\circ} \mathrm{C}$. Then macrobenthos and sediment were ground with a mortar and pestle. The $\mathrm{C}$ and $\mathrm{N}$ stable isotopic compositions of these samples were determined by a continuous flow, isotope ratio, mass spectrometer system (Europa, Hydra 20/20) at the University of California Davis Stable Isotope Facility. Isotopic compositions were reported as parts per thousand deviations (\%o) from Pee Dee Belemnite for carbon $\left(\delta^{13} \mathrm{C}\right)$ and from air for nitrogen $\left(\delta^{15} \mathrm{~N}\right)$. In this analysis $\mathrm{C}$ and $\mathrm{N}$ contents of the samples were also obtained as percentage of dry mass.

Chl $a$ and phaeo $a$ of the surface sediment samples were extracted by $90 \%$ acetone and their concentrations were determined by spectrophotometric measurement (Bausch \& Lomb, Spectronic 20) following the method of Lorenzen (1967). The chl a on the GF/F filter samples from river water was also extracted by $90 \%$ acetone and determined by fluorometric measurement (Turner Designs, TD-700). Organic matter in the sediment samples was determined by dry mass loss by ignition at $550^{\circ} \mathrm{C}$ for $2 \mathrm{~h}$. The concentrations of dissolved inorganic nitrogen and phosphorus, and dissolved organic carbon (DOC) in the water samples, were determined using auto-analyzers (Bran+Luebbe, TRAACS-800; Shimadzu, TOC-5050).

Data analyses. Differences in river water quality were tested by 2-way ANOVA with rivers and sampling dates as main effects. Differences in tidal flat sediment properties were also tested by 2-way ANOVA with estuaries and stations as main effects, using the data from July 2004. When the ANOVAs detected significant differences among the rivers or estuaries, Tukey's HSD test (or Tukey-Kramer test in cases when the sample nos. were unbalanced) was performed for multiple comparisons. Furthermore, the seasonal variations in organic carbon content, C:N, chl a content and phaeo a content of tidal flat sediments were tested by 2-way ANOVA with estuaries and seasons as main effects. For this ANOVA, as seasonal data were not obtained at some stations, data from 1 station of each estuary, i.e. $\mathrm{FR}_{\mathrm{b}}, \mathrm{AG} 1_{\mathrm{c}}, \mathrm{AG} 2_{\mathrm{b}}$, were considered representative of the estuary. The differences in $\mathrm{POM}_{\mathrm{O}}$ (i.e. C:N and particulate organic carbon, POC, concentration) between FR and AG were tested by a paired $t$ test, matching the 2 sites by sampling season. In addition, we conducted multivariate analysis of variance (MANOVA) to determine sources of variation in $\delta^{13} \mathrm{C}$ and $\delta^{15} \mathrm{~N}$ of tidal flat macrobenthos. As the number of species that were found in all the estuaries were limited, i.e. 5 species, macrobenthos species at each station in each season were pooled into 5 groups, i.e. bivalves, amphipods, crabs, snails and polychaetes, and then averaged. The dependent variables were $\delta^{13} \mathrm{C}$ and $\delta^{15} \mathrm{~N}$ of macrobenthos, and sources of variation were estuaries $(n=3)$, seasons $(n=4)$, stations $(n=$ 4 in each estuary) and macrobenthos groups ( $n=5)$. Note that seasonal data sets were obtained only at the 4 stations, and in the other 8 stations we had data for only July 2004 due to the sampling design (see 'Field sampling and sample processing'). If the MANOVA detected significant differences, it was followed by the least-square means multiple comparison procedure. In advance to the above statistical tests, Shapiro-Wilk test and Levene's test were performed to test the data sets for normality and homogeneity of variance, respectively. The data for concentrations of POC, DOC and $\mathrm{chl} a$ in river and offshore waters were log-transformed to satisfy normality and homogeneity of variance. We used SAS version 9.1 (SAS) for the statistical analyses.

Based on the $\delta^{13} \mathrm{C}$ and $\delta^{15} \mathrm{~N}$ results, we estimated the relative importance of potential sources for SPOM and diets of primary consumers using IsoSource, the mixing model developed by Phillips \& Gregg (2003). Omnivores or predators were not included in the estimation. In the calculation, 1 and $3 \%$ were subtracted from $\delta^{13} \mathrm{C}$ and $\delta^{15} \mathrm{~N}$ of the primary consumers, respectively, except amphipods, taking into account trophic fractionation (e.g. DeNiro \& Epstein 1978, Minagawa $\&$ Wada 1984). These values have been widely used in mixing model calculations (e.g. Kang et al. 2003, Yokoyama \& Ishihi 2003). For amphipods, however, the trophic fractionations of $\delta^{13} \mathrm{C}$ and $\delta^{15} \mathrm{~N}$ were considered 1 and $2.5 \%$, respectively, since the subtraction of $3 \%$ for $\delta^{15} \mathrm{~N}$ resulted in making the signatures out of the range for potential food sources and no output calculation. In each estuary, $\delta^{13} \mathrm{C}$ and $\delta^{15} \mathrm{~N}$ of each macrobenthos species from different sampling occasions and different sampling stations were averaged. This was based on the fact that MANOVA showed that the stable isotopic signatures of macrobenthos did not differ significantly among seasons or stations within each estuary. We considered those values to be 
annually representative, although at 8 stations the stable isotopic signatures of macrobenthos were determined only in July 2004. Likewise, for SPOM, $\mathrm{POM}_{\mathrm{R}}$ and $\mathrm{POM}_{\mathrm{O}}$, stable isotopic data from different sampling occasions were averaged and considered annually representative values. However, seasonal data of benthic microalgae were not pooled, since their isotopic signatures differed greatly among seasons and the sample nos. were not sufficient to obtain annual means with small standard errors. Although macroalgae and eelgrass were not sampled in FR, $\delta^{13} \mathrm{C}$ and $\delta^{15} \mathrm{~N}$ for those materials in AG1 and AG2 were interpolated to the IsoSource calculation for FR to compare estimation results under the same calculation conditions. Furthermore, to test sensitivity of the calculation outputs from the IsoSource model to some of the given calculation conditions, we conducted trial calculations switching the stable isotopic signatures of $\mathrm{POM}_{\mathrm{O}}$ between $\mathrm{SG}$ and $\mathrm{BI}$, excluding seagrass as a potential source of organic matter and assigning smaller values of $\delta^{15} \mathrm{~N}$ as trophic fractionation (1\%o for amphipods and $1.5 \%$ for the other macrobenthos groups). Those trial conditions did not have much effect on the relative importance of the potential sources, indicating that the outputs from our IsoSouce calculations were sufficiently robust.

\section{RESULTS}

\section{Chemical characteristics of the river waters and tidal flat sediments}

On average, both the POC and chl a concentrations of river water were about one order of magnitude higher in $\mathrm{R}_{\mathrm{AG} 1}$ and $\mathrm{R}_{\mathrm{AG} 2}$ than $\mathrm{R}_{\mathrm{FR} 1}$ and $\mathrm{R}_{\mathrm{FR} 2}$ (Table 1).
Table 2. POC concentrations and $\mathrm{C}: \mathrm{N}$ of POM in offshore water. Estuaries fed by rivers with (FR) mixed forested/urban and (AG1, AG2) agricultural watersheds. Mean \pm SE of 3 sampling dates are shown

\begin{tabular}{|lcc|}
\hline & POC $\left(\mathrm{mg} \mathrm{l}^{-1}\right)$ & C:N \\
\hline FR & $0.16 \pm 0.06$ & $6.2 \pm 0.6$ \\
AG1 \& AG2 & $0.19 \pm 0.07$ & $5.1 \pm 0.3$ \\
\hline
\end{tabular}

The C:N of $\mathrm{POM}_{\mathrm{R}}$ was significantly higher in $\mathrm{R}_{\mathrm{FR} 1}$ and $\mathrm{R}_{\mathrm{FR} 2}$ than in $\mathrm{R}_{\mathrm{AG} 1}$ and $\mathrm{R}_{\mathrm{AG} 2}$. Either $\mathrm{C}: \mathrm{N}$ of $\mathrm{POM}_{\mathrm{O}}$ or $\mathrm{POC}$ concentration in the offshore waters did not significantly differ among the estuaries (paired $t$-test of FR versus AG1 and AG2 for the mean of 3 sampling dates: POC $;=-0.428, \mathrm{p}=0.710, \mathrm{df}=2, \mathrm{C}: \mathrm{N}_{i} t=-3.054, \mathrm{p}=$ 0.093 , df $=2$ ) (Table 2). POC concentration of the river water in FR was almost equivalent with that of the offshore water, whereas POC concentrations of the river waters in AG1 and AG2 were much higher than that of the offshore water. In all the estuaries, C:N of $\mathrm{POM}_{\mathrm{O}}$ was lower than that of the river waters.

In July 2004, SPOM of the tidal flat in FR was higher in organic carbon content and $\mathrm{C}: \mathrm{N}$, compared with the other 2 estuaries with agricultural watersheds (Table 3). The mud, chl a and phaeo a contents of the sediments did not differ significantly among the estuaries in July 2004. The tidal flat sediments did not have a significant seasonal variation in organic carbon, C:N, chl a or phaeo a (2-way ANOVA, the factor of seasons: $p>0.05$ for all the constituents, the factor of estuaries: $\mathrm{p}<0.05$ for organic carbon and $\mathrm{C}: \mathrm{N}$, and $\mathrm{p}>0.05$ for chl $a$ and phaeo $a$ ). SPOM of FR contained more of the large-size fractions, such as $>500 \mu \mathrm{m}$, and was less sorted, except that in the most offshore point $\left(\mathrm{FR}_{\mathrm{d}}\right)$, fine

Table 1. Water chemistry of the rivers discharging into the study estuaries $\left(\mathrm{R}_{\mathrm{FR} 1}\right.$ and $\mathrm{R}_{\mathrm{FR} 2}$ : rivers fed by mixed forested/urban watersheds; $\mathrm{R}_{\mathrm{AG} 1}$ and $\mathrm{R}_{\mathrm{AG} 2}$ : rivers fed by agricultural watersheds). Means $\pm \mathrm{SE}$ of periodic samplings are shown $\left(\mathrm{NO}_{3}{ }^{-}, \mathrm{NH}_{4}{ }^{+}\right.$, $\mathrm{PO}_{4}{ }^{3-}$ and DOC, $\mathrm{n}=6$; chl $a_{1} \mathrm{n}=12$ to 14 ; POC and $\mathrm{C}: \mathrm{N}, \mathrm{n}=8$ to 11$)$. ANOVA results ( $F$ and $\mathrm{p}$ values) are also shown for the difference between the rivers and sampling dates. Different letters indicate significant difference $(p<0.05)$ among rivers based on multiple comparisons

\begin{tabular}{|c|c|c|c|c|c|c|c|}
\hline & $\begin{array}{c}\mathrm{NO}_{3}^{-} \\
\left(\mathrm{mg} \mathrm{l}^{-1}\right)\end{array}$ & $\begin{array}{c}\mathrm{NH}_{4}^{+} \\
\left(\mathrm{mg} \mathrm{l}^{-1}\right)\end{array}$ & $\begin{array}{c}\mathrm{PO}_{4}{ }^{3-} \\
\left(\mathrm{mg} \mathrm{l}^{-1}\right)\end{array}$ & $\begin{array}{c}\text { DOC } \\
\left(\mathrm{mg} \mathrm{l}^{-1}\right)\end{array}$ & $\begin{array}{c}\mathrm{POC} \\
\left(\mathrm{mg} \mathrm{l}^{-1}\right)\end{array}$ & $\mathrm{C}: \mathrm{N}$ & $\begin{array}{c}\text { Chl a } \\
\left(\mu \mathrm{g} \mathrm{l}^{-1}\right)\end{array}$ \\
\hline $\mathrm{R}_{\mathrm{FR} 1}$ & $0.91 \pm 0.29^{\mathrm{a}}$ & $0.03 \pm 0.01$ & $0.01 \pm 0.00$ & $6.0 \pm 0.3^{\mathrm{a}, \mathrm{b}}$ & $0.13 \pm 0.04^{\mathrm{a}}$ & $8.6 \pm 0.4^{b}$ & $0.36 \pm 0.10^{\mathrm{a}}$ \\
\hline $\mathrm{R}_{\mathrm{FR} 2}$ & $2.40 \pm 0.33^{a, b}$ & $0.02 \pm 0.01$ & $0.01 \pm 0.00$ & $5.0 \pm 2.8^{\mathrm{a}}$ & $0.21 \pm 0.04^{\mathrm{a}}$ & $10.1 \pm 0.3^{c}$ & $0.39 \pm 0.06^{a}$ \\
\hline $\mathrm{R}_{\mathrm{AG} 1}$ & $2.66 \pm 0.50^{b}$ & $0.01 \pm 0.00$ & $0.02 \pm 0.01$ & $11.2 \pm 3.6^{\mathrm{b}, \mathrm{c}}$ & $1.46 \pm 0.38^{\mathrm{a}, \mathrm{b}}$ & $7.0 \pm 0.4^{\mathrm{a}}$ & $9.4 \pm 2.8^{\mathrm{b}}$ \\
\hline $\mathrm{R}_{\mathrm{AG} 2}$ & $1.31 \pm 0.42^{\mathrm{a}, \mathrm{b}}$ & $0.11 \pm 0.08$ & $0.02 \pm 0.01$ & $22.9 \pm 2.9^{c}$ & $2.61 \pm 0.74^{b}$ & $6.7 \pm 0.4^{\mathrm{a}}$ & $10.3 \pm 2.2^{\mathrm{b}}$ \\
\hline \multicolumn{8}{|l|}{ Rivers } \\
\hline$F$ & $F_{3,15}=4.29$ & $F_{3,15}=1.33$ & $F_{3,15}=2.54$ & $F_{3,15}=11.98$ & $F_{3,28}=112.9$ & $F_{3,27}=26.42$ & $F_{3,34}=134.3$ \\
\hline $\mathrm{p}$ & 0.023 & 0.301 & 0.100 & 0.0003 & $<0.0001$ & $<0.0001$ & $<0.0001$ \\
\hline \multicolumn{8}{|l|}{ Dates } \\
\hline$F$ & $F_{5,15}=0.72$ & $F_{5,15}=1.23$ & $F_{5,15}=4.96$ & $F_{5,15}=3.47$ & $F_{10,28}=6.34$ & $F_{10,27}=4.87$ & $F_{13,34}=4.84$ \\
\hline $\mathrm{p}$ & 0.618 & 0.343 & 0.0070 & 0.0277 & $<0.0001$ & 0.0005 & 0.0001 \\
\hline
\end{tabular}


Table 3. Sediment properties of the estuarine tidal flats in July 2004. Estuaries fed by rivers with (FR) mixed forested/urban and (AG1, AG2) agricultural watersheds. For median grain size, ranges over the 4 sampling stations in each estuary based on a single measurement are shown. '<63' indicates that median grain size is smaller than $63 \mu \mathrm{m}$. For the other constituents, values are mean $\pm \mathrm{SE}$ and range. ANOVA results ( $F$ and $\mathrm{p}$ values) are also shown for the difference between the estuaries and stations. Different letters indicate significant difference $(\mathrm{p}<0.05)$ between the estuaries based on multiple comparisons

\begin{tabular}{|c|c|c|c|c|c|c|c|c|c|c|}
\hline \multirow{2}{*}{\multicolumn{2}{|c|}{$\begin{array}{l}\text { Median grain } \\
\text { size }(\mu \mathrm{m})\end{array}$}} & \multicolumn{2}{|c|}{$\begin{array}{l}\text { Mud content } \\
(\%)\end{array}$} & \multicolumn{2}{|c|}{$\begin{array}{c}\text { Organic C content } \\
(\%)\end{array}$} & \multicolumn{2}{|c|}{$\mathrm{C}: \mathrm{N}$} & \multicolumn{2}{|c|}{$\begin{array}{c}\mathrm{Chl} \mathrm{a} \\
\left(\mathrm{mg} \mathrm{m}^{-2}\right)\end{array}$} & $\begin{array}{c}\text { Phaeo a } \\
\left(\mathrm{mg} \mathrm{m}^{-2}\right)\end{array}$ \\
\hline & & Mean & Range & Mean & Range & Mean & Range & Mean & Range & Mean Range \\
\hline FR & $<63-141$ & $43 \pm 12$ & $21-85$ & $1.94 \pm 0.38^{\mathrm{a}}$ & $1.45-3.06$ & $17.9 \pm 0.6^{\mathrm{a}}$ & $16.8-19.4$ & $79 \pm 48$ & $29-132$ & $381 \pm 48293-513$ \\
\hline AG1 & $<63-244$ & $31 \pm 15$ & $0.2-70$ & $0.98 \pm 0.54^{\mathrm{a}, \mathrm{b}}$ & $0.14-2.54$ & $9.6 \pm 0.2^{\mathrm{b}}$ & $9.1-9.9$ & $55 \pm 15$ & $44-100$ & $226 \pm 49 \quad 80-289$ \\
\hline AG2 & $110-161$ & $14 \pm 3$ & $10-17$ & $0.31 \pm 0.05^{\mathrm{b}}$ & $0.16-0.41$ & $8.2 \pm 0.3^{b}$ & $7.5-8.9$ & $81 \pm 35$ & $24-176$ & $361 \pm 77254-571$ \\
\hline \multicolumn{11}{|c|}{ Estuaries } \\
\hline$F$ & & \multirow{2}{*}{\multicolumn{2}{|c|}{$\begin{array}{c}F_{2,6}=1.15 \\
0.379\end{array}$}} & \multirow{2}{*}{\multicolumn{2}{|c|}{$\begin{array}{c}F_{2,6}=8.32 \\
0.019\end{array}$}} & \multirow{2}{*}{\multicolumn{2}{|c|}{$\begin{array}{c}F_{2,6}=206.7 \\
<0.0001\end{array}$}} & \multirow{2}{*}{\multicolumn{2}{|c|}{$\begin{array}{c}F_{2,6}=0.61 \\
0.575\end{array}$}} & $F_{2,6}=1.63$ \\
\hline $\mathrm{p}$ & & & & & & & & & & 0.272 \\
\hline \multicolumn{11}{|c|}{ Stations } \\
\hline$F$ & & \multirow{2}{*}{\multicolumn{2}{|c|}{$\begin{array}{l}F_{3,6}=0.50 \\
0.697\end{array}$}} & \multirow{2}{*}{\multicolumn{2}{|c|}{$\begin{array}{c}F_{3,6}=3.47 \\
0.091\end{array}$}} & \multirow{2}{*}{\multicolumn{2}{|c|}{$\begin{array}{c}F_{3,6}=2.25 \\
0.183\end{array}$}} & \multirow{2}{*}{\multicolumn{2}{|c|}{$\begin{array}{c}F_{3,6}=3.73 \\
0.080\end{array}$}} & \multirow{2}{*}{$\begin{array}{c}F_{3,6}=0.45 \\
0.725\end{array}$} \\
\hline $\mathrm{p}$ & & & & & & & & & & \\
\hline
\end{tabular}

fractions $(<63 \mu \mathrm{m})$ dominated (Fig. 2). In FR, little pieces of wood and leaf debris were apparent in the sediment samples. SPOM of AG1 and AG2 was finer and more sorted compared with that of FR. In AG1, SPOM of $A G 1_{d}$ was more sorted and coarser than that of the other stations, $\mathrm{AG} 1_{\mathrm{a}-\mathrm{c}}$.

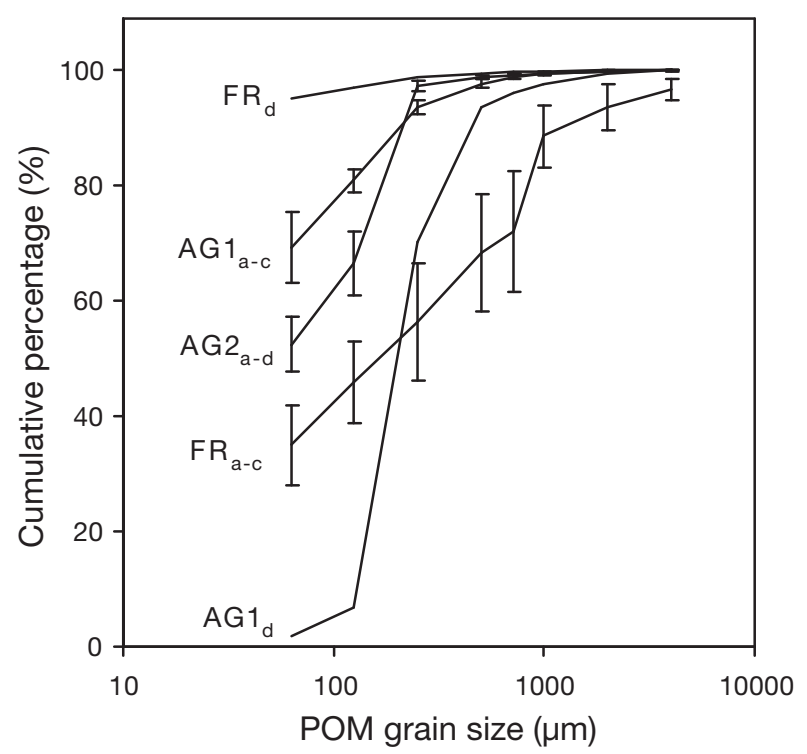

Fig. 2. Grain size distributions of POM in the tidal flat sediments. Estuaries fed by rivers with (FR) mixed forested/urban and (AG1, AG2) agricultural watersheds. The vertical axis shows cumulative percentages of total mass of POM passing through sieves of given mesh sizes. $\mathrm{FR}_{\mathrm{a}-\mathrm{c}}$ is mean of the 3 stations, $\mathrm{FR}_{\mathrm{a}}, \mathrm{FR}_{\mathrm{b}}$ and $\mathrm{FR}_{\mathrm{c}}(\mathrm{n}=3) ; \mathrm{FR}_{\mathrm{d}}$, which had markedly different distributions, is shown separately. Likewise, $A G 1_{a-c}$ indicates mean of the 3 stations $(n=3)$, and $A G 1_{d}$ is shown separately. AG2 $2_{a-d}$ shows mean of the 4 stations $(n=4)$. Error bars: \pm SE

\section{$\mathrm{C}$ and $\mathrm{N}$ stable isotopes}

Thirteen species were analyzed for $\delta^{13} \mathrm{C}$ and $\delta^{15} \mathrm{~N}$ of macrobenthos: bivalves Mya arenaria, Macoma balthica, Nuttallia obscurata and Venerupis philippinarum; amphipods Corophium spinicorne; polychaetes Nephtys longosetosa, Abarenicola claparedi, Neanthes succinea, Nectoneanthes virens and Hemipodus borealis; snails Batillaria attramentaria and Ilyanassa obsoleta and crab Hemigrapsus oregonensis (Fig. 3). Five of the 13 species were collected in all of the estuaries: $M$. arenaria, $M$. balthica, C. spinicorne, N. longosetosa and $A$. claparedi. The $\delta^{13} \mathrm{C}$ and $\delta^{15} \mathrm{~N}$ of most macrobenthos species and SPOM were lower in FR than AG1 and AG2. The polychaetes showed relatively high $\delta^{15} \mathrm{~N}$, and the snails were relatively high in both $\delta^{13} \mathrm{C}$ and $\delta^{15} \mathrm{~N}$ (Figs. $3 \& 4$ ). The amphipods had a relatively low $\delta^{15} \mathrm{~N}$ signature in all the estuaries. The bivalves showed wide ranges in their stable isotope signatures depending on species. N. obscurata had relatively low $\delta^{13} \mathrm{C}$, whereas $M$. balthica was relatively high in both $\delta^{13} \mathrm{C}$ and $\delta^{15} \mathrm{~N}$. In general, deposit-feeding macrobenthos showed relatively higher $\delta^{15} \mathrm{~N}$ than suspension-feeding macrobenthos. The results of MANOVA showed that $\delta^{13} \mathrm{C}$ and $\delta^{15} \mathrm{~N}$ of macrobenthos differed significantly among the estuaries and macrobenthos groups but did not vary significantly among the seasons and sampling stations of each estuary (Table 4). In particular, it was shown that macrobenthos $\delta^{13} \mathrm{C}$ and $\delta^{15} \mathrm{~N}$ of FR differed significantly from those of AG1 and AG2 (Table 5).

The $\delta^{13} \mathrm{C}$ and $\delta^{15} \mathrm{~N}$ of $\mathrm{POM}_{\mathrm{R}}$ and $\mathrm{POM}_{\mathrm{O}}$ also differed among the rivers. In all the estuaries, $\delta^{13} \mathrm{C}$ and $\delta^{15} \mathrm{~N}$ of benthic microalgae had a seasonal pattern, i.e. high $\delta^{13} \mathrm{C}$ and low $\delta^{15} \mathrm{~N}$ in spring and high $\delta^{15} \mathrm{~N}$ in summer (Figs. $3 \& 4$ ). The magnitude of the seasonal variation 


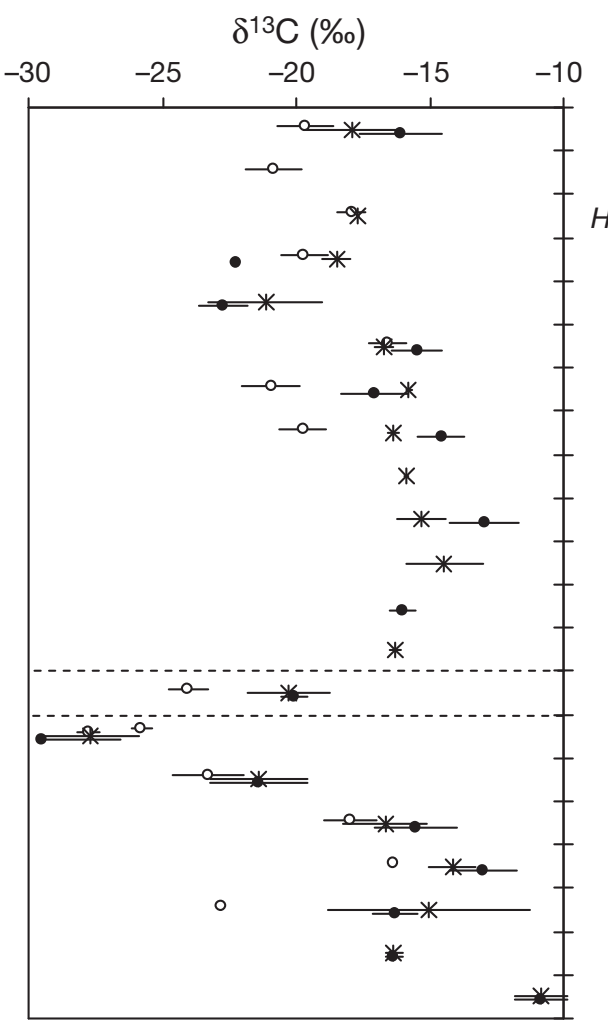

Corophium spinicorne $\left(\mathrm{a}, \mathrm{SD}^{1 * *}\right)$

Venerupis philippinarum $\left(\mathrm{b}, \mathrm{S}^{2}\right)$

Hemigrapsus oregonensis (c, $\mathrm{O}^{3}$ )

Mya arenaria $\left(b, S^{4,5}\right)$

Nuttallia obscurata (b, SD ${ }^{6 *}$ )

Macoma balthica (b, $\mathrm{SD}^{7 * *}$ )

Abarenicola claparedi ( $\left.\mathrm{p}, \mathrm{D}^{8,9 *}\right)$

Nephtys longosetosa ( $\left.\mathrm{p}, \mathrm{P}^{10,11 *}\right)$

Neanthes succinea $\left(\mathrm{p}, \mathrm{O}^{11,12 \star}\right)$

Batillaria attramentaria (s, $\mathrm{D}^{13}$ )

Ilyanassa obsoleta (s, D ${ }^{14}$ )

Nectoneanthes virens ( $\left.\mathrm{p}, \mathrm{P}^{10,11}\right)$

Hemipodus borealis ( $\mathrm{p}, \mathrm{O}^{5,11 *}$ )

Sediment POM

River POM

Offshore POM

Benthic microalgae (summer)

Benthic micoroalgae (spring)

Benthic microalgae (fall)

Ulva sp. (macroalgae)

Zostera marina (seagrass)

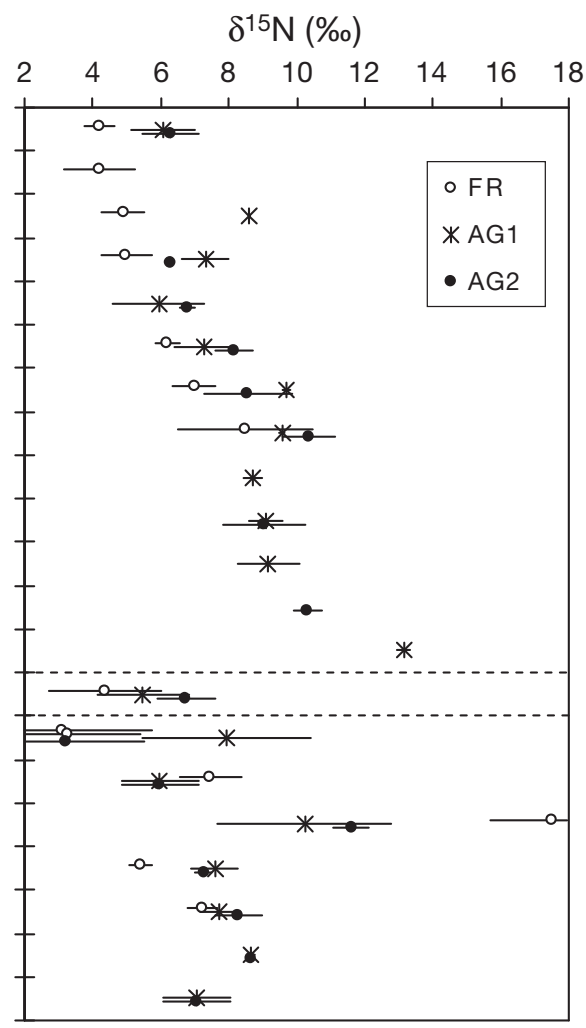

Fig. 3. $\delta^{13} \mathrm{C}$ and $\delta^{15} \mathrm{~N}$ of macrobenthos, SPOM and potential POM sources from estuaries fed by rivers with (FR) mixed forested/urban and (AG1, AG2) agricultural watersheds. The plots and error bars indicate mean and SD, respectively. Offshore POM for AG1 and AG2 are results for identical samples. Zostera marina and Ulva sp. (macroalgae) were averages of AG1 and AG2. In each estuary, each macrobenthos species from all the sampling points and all the sampling occasions were pooled and averaged ( $\mathrm{n}=3$ to 12 for each species). Taking account of trophic fractionation for one trophic step, 1 and $3 \%$ were subtracted from all the macrobenthos $\delta^{13} \mathrm{C}$ and $\delta^{15} \mathrm{~N}$, respectively. Macrobenthos groups: a, amphipod; b, bivalve; $\mathrm{c}$, crab; $\mathrm{s}$, snail and p, polychaete. Feeding types: $\mathrm{S}$, suspension feeder; $\mathrm{D}$, deposit feeder; $\mathrm{O}$, omnivore and $\mathrm{P}$, predator. Information source for feeding types: ${ }^{1}$ Riisgård \& Kamermans (2001), ${ }^{2}$ Nakamura (2001), ${ }^{3}$ Behrens-Yamada \& Boulding (1998), ${ }^{4}$ Forster \& Zettler (2004), ${ }^{5}$ referenced by Martinetto et al. (2006), ${ }^{6}$ Akiyama (1988), ${ }^{7}$ Peterson \& Skilleter (1994), ${ }^{8}$ Hymel \& Plante (2000), ${ }^{9}$ Andresen \& Kristensen (2002), ${ }^{10}$ Caron et al. (2004), ${ }^{11}$ referenced by Commito \& Ambrose (1985), ${ }^{12}$ Pardo \& Dauer (2003), ${ }^{13}$ Whitlatch \& Obrebski (1980) and ${ }^{14}$ Kelaher et al. (2003). ${ }^{*}$ Based on information for another species of same family, ${ }^{* *}$ opportunistically changes feeding types

was greatest in FR. $\delta^{13} \mathrm{C}$ and $\delta^{15} \mathrm{~N}$ of $\mathrm{POM}_{\mathrm{R}}$ and $\mathrm{POM}_{\mathrm{O}}$ did not show seasonality. Ulva sp. had $\delta^{13} \mathrm{C}$ and $\delta^{15} \mathrm{~N}$ close to benthic algae, whereas Zostera marina showed much higher $\delta^{13} \mathrm{C}$ than the other POM sources. The ranks of $\delta^{15} \mathrm{~N}$ values among potential sources, particularly benthic microalgae, $\mathrm{POM}_{\mathrm{R}}$ and $\mathrm{POM}_{\mathrm{O}}$, differed among the estuaries. This caused different shapes of polygons formed by those potential sources in the $\delta^{13} \mathrm{C}-\delta^{15} \mathrm{~N}$ biplots.

\section{Relative importance of potential sources}

In FR, $\mathrm{POM}_{\mathrm{R}}$ was estimated to contribute to the nutrition of Mya arenaria, Venerupis philippinarum and Corophium spinicorne (37 to $48 \%$ ) (Fig. 5). For those macrobenthos in FR, benthic microalgae (spring) was also suggested to be an important food source (35 to $45 \%$ ), although the estimation had high variation (i.e. relatively large standard deviation). For Macoma balthica in FR, benthic microalgae (spring) and seagrass were estimated to be relatively important food sources (38 and 30\%, respectively). Particular sources for the diet of Abarenicola claparedi were not clear. $\mathrm{SPOM}$ in FR was dominated by $\mathrm{POM}_{\mathrm{R}}$ (ca. 70\%). In AG1, $\mathrm{POM}_{\mathrm{O}}$ was the important food source for Nuttallia obscurata, C. spinicorne and $M$. arenaria (31 to $90 \%$ ). Benthic microalgae (summer) were estimated to be the most important food source for Abarenicola claparedi, Ilyanassa obsoleta and Batillaria attramentaria (51 to $72 \%$ ) in AG1. Food sources for M. balthica in AG1 were widely distributed without any source showing dominance. A significant contribution of $\mathrm{POM}_{\mathrm{R}}$ to macrobenthos diet was not detected in AG1. 
IsoSource could not determine a dominant source for SPOM in AG1 due to the stable signatures falling outside the ranges of potential sources. In AG2, N. obscurata and $M$. arenaria were estimated to use $\mathrm{POM}_{\mathrm{R}}$ nutritionally (43 to $48 \%$ ). Benthic microalgae (summer)
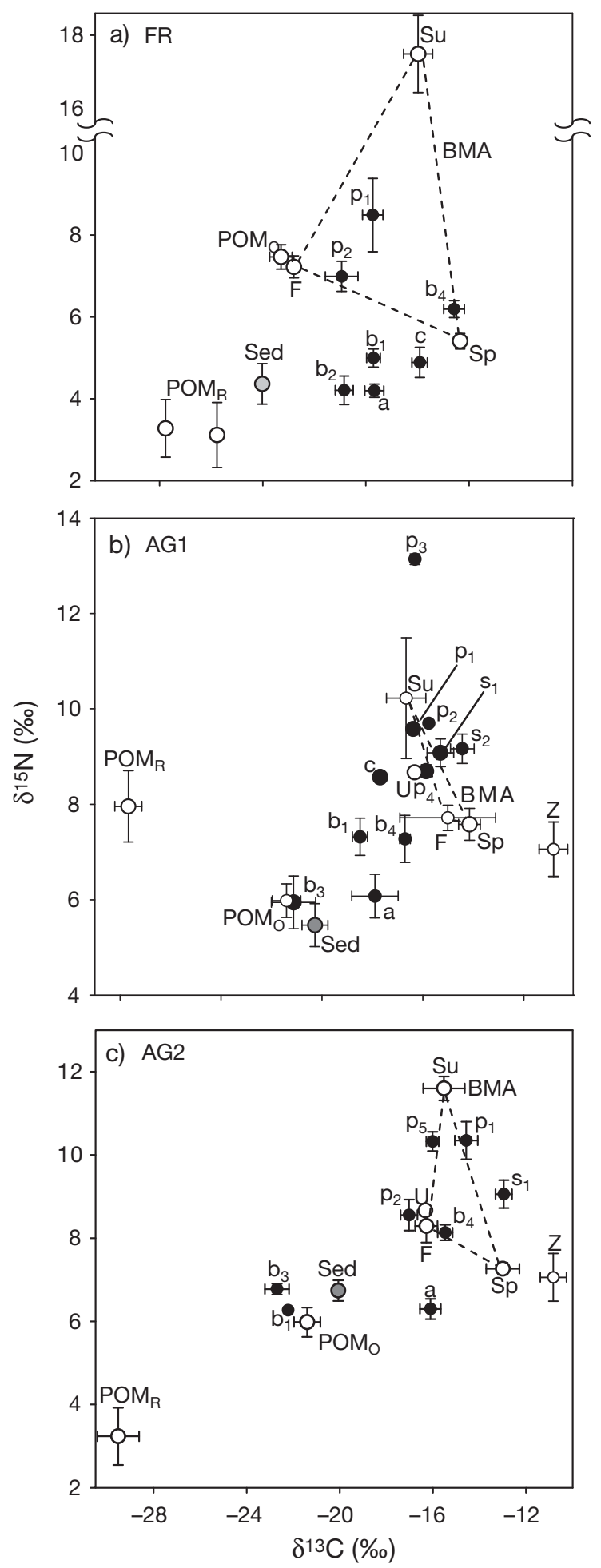

were shown to be assimilated by $N$. obscurata, B. attramentaria and A. claparedi (29 to $39 \%$ ) in AG2. The seagrass contributed to $B$. attramentaria and C. spinicorne (29 to $48 \%$ ). No particular source dominating SPOM in AG2 was found.

Although potential sources for SPOM in AG1 were not determined by IsoSource, geometric observation of the $\delta^{13} \mathrm{C}-\delta^{15} \mathrm{~N}$ biplot suggests dominance of $\mathrm{POM}_{\mathrm{O}}$ in SPOM. Meanwhile, the IsoSource calculation suggested a significant contribution of $\mathrm{POM}_{\mathrm{R}}$ to the diets of the 2 bivalve species, Nuttallia obscurata and Mya arenaria, with a lesser contribution of $\mathrm{POM}_{\mathrm{O}}$ in $\mathrm{AG} 2$. However, the polygons in the $\delta^{13} \mathrm{C}-\delta^{15} \mathrm{~N}$ biplot of AG2 formed by potential sources were relatively narrower than those of the other estuaries, which potentially lowers the accuracy of the IsoSource estimation (Phillips \& Gregg 2003). The stable isotopic signatures of those species were geometrically close to those of $\mathrm{POM}_{\mathrm{O}}$ on the $\delta^{13} \mathrm{C}-\delta^{15} \mathrm{~N}$ biplot, suggesting the possible contribution of $\mathrm{POM}_{\mathrm{O}}$ to those species. Hence, the results of the IsoSource calculation in AG2 need to be carefully interpreted, and possible overestimation in the contributions of $\mathrm{POM}_{\mathrm{R}}$ to those 2 species should be taken into account.

\section{DISCUSSION}

\section{$\mathrm{POM}_{R}$ effects on chemical properties of the tidal flat sediments}

In general, riparian forests provide rivers with litter and wood and can also significantly constrain primary productivity of periphyton due to light limitation by their canopies (Webster \& Waide 1982, Kiffney et al.

Fig. 4. $\delta^{13} \mathrm{C}$ and $\delta^{15} \mathrm{~N}$ of macrobenthos (black circles), potential food sources (white circles) and sediment (grey circles) in estuaries fed by rivers with (a) FR: mixed forested/urban and $(\mathrm{b}, \mathrm{c})$ AG1 and AG2: agricultural watersheds. The plots and error bars indicate mean and SE, respectively. In each estuary, each macrobenthos species from all sampling stations and sampling occasions were pooled and averaged ( $\mathrm{n}=3$ to 12 for each species). Likewise, results for SPOM were also spatially and temporally pooled in each estuary. Taking account of trophic fractionation for one trophic step, 1 and 3\% were subtracted from all the macrobenthos $\delta^{13} \mathrm{C}$ and $\delta^{15} \mathrm{~N}$, respectively. $b_{1}$, Mya arenaria; $b_{2}$, Venerupis philippinarum; $\mathrm{b}_{3}$, Nuttallia obscurata; $\mathrm{b}_{4}$, Macoma balthica; $\mathrm{a}$, Corophium spinicorne; $\mathrm{c}$, Hemigrapsus oregonensis; $\mathrm{s}_{1}$, Batillaria attramentaria; $\mathrm{s}_{2}$, Ilyanassa obsoleta; $\mathrm{p}_{1}$, Nephtys longosetosa; $\mathrm{p}_{2}$, Abarenicola claparedi; $\mathrm{p}_{3}$, Hemipodus borealis; $\mathrm{p}_{4}$, Neanthes succinea; $\mathrm{p}_{5}$, Nectoneanthes virens; Sed, sediment POM ( $\mathrm{n}=12$ to 14$) ; \mathrm{POM}_{\mathrm{R}}$, river water POM ( $\mathrm{n}=12$ to 14$) ; \mathrm{POM}_{\mathrm{O}}$, offshore seawater POM (n = 3); BMA, benthic microalgae $(\mathrm{Su}$, summer; $\mathrm{F}$, fall and $\mathrm{Sp}$, spring, $\mathrm{n}=3$ to 4 for each season); U, Ulva sp. (macroalgae, $\mathrm{n}=3$ ) and $\mathrm{Z}$, Zostera marina (seagrass, $\mathrm{n}=3$ ) 
Table 4. MANOVA results based on Wilks' Lambda calculations. Effects of estuaries (FR, AG1 and AG2), sampling stations (4 relative distances from upper end of the tidal area), seasons (July and October 2004, February and May 2005) and macrobenthos groups (amphipods, bivalves, crabs, polychaetes and snails) on macrobenthos $\delta^{13} \mathrm{C}$ and $\delta^{15} \mathrm{~N}$ were tested

\begin{tabular}{|lrcc|}
\hline Effect & \multicolumn{1}{c}{$F$} & $\mathrm{df}$ & $\mathrm{p}$ \\
\hline Estuaries & 15.52 & 4,116 & $<0.0001$ \\
Season & 0.86 & 6,116 & 0.529 \\
Station & 0.78 & 6,116 & 0.590 \\
Species & 10.57 & 8,116 & $<0.0001$ \\
\hline
\end{tabular}

Table 5. Comparisons of macrobenthos $\delta^{13} \mathrm{C}$ and $\delta^{15} \mathrm{~N}$ among the estuaries fed by rivers with (FR) mixed forested/urban and (AG1, AG2) agricultural watersheds. p-values for the hypothesis that least squares means are equal between 2 estuaries being contrasted are shown

\begin{tabular}{|lcl|}
\hline Combinations of estuaries & $\delta^{13} \mathrm{C}$ & $\delta^{15} \mathrm{~N}$ \\
\hline FR - AG1 & $<0.0001$ & 0.0001 \\
FR - AG2 & $<0.0001$ & 0.0002 \\
AG1 - AG2 & 0.002 & 0.754 \\
\hline
\end{tabular}

2003, Roy et al. 2005). The remarkably low chl a concentration in the rivers of FR suggests low primary productivity, which can probably be attributed to the high degree of canopy closure. Furthermore, in the tidal flat of $\mathrm{FR}$, the high $\mathrm{C}: \mathrm{N}$, coarse grain size and depleted $\delta^{13} \mathrm{C}$ and $\delta^{15} \mathrm{~N}$ of SPOM indicate substantial sedimentation of terrestrial-origin $\mathrm{POM}_{\mathrm{R}}$. By contrast, the high chl a concentration and low $\mathrm{C}: \mathrm{N}$ in $\mathrm{AG} 1$ and $\mathrm{AG} 2$ indicate that $\mathrm{POM}_{\mathrm{R}}$ was dominated by algal material produced in the rivers and with a lower contribution from terrestrial-origin material. This is probably due to the contrasting watershed characteristics from FR: less canopy and diminished sources of terrestrial POM. In the present study, the quality of $\mathrm{POM}_{\mathrm{R}}$ reflected the watershed characteristics.

$\mathrm{POM}_{R}$ supply to the estuary was probably much smaller in FR than in AG1, because both the $\mathrm{POM}_{R}$ concentration and discharge were much smaller in the rivers of FR. Nevertheless, $\mathrm{POM}_{R}$ dominated SPOM in $\mathrm{FR}$, whereas $\mathrm{POM}_{\mathrm{O}}$ dominated in $\mathrm{AG} 1$ or $\mathrm{AG}$. Enríquez et al. (1993) showed that decomposition rates of terrestrial-origin POM are about one order of magnitude smaller than that of microalgae. Hence, the lower degradability of the terrestrial-origin POM may have led to its long residence time and dominance of $\mathrm{POM}_{\mathrm{R}}$ in SPOM of FR. Middleburg et al. (2000) reported the residence time of organic carbon originating from microphytobenthos as 2.4 and $5.6 \mathrm{~d}$ in sandy and muddy intertidal sediments, respectively. Ehren- hauss et al. (2004) showed that $28 \%$ of diatom carbon experimentally added to permeable sediments was decomposed in $1 \mathrm{~d}$. The dominance of highly degradable algal material in $\mathrm{POM}_{\mathrm{R}}$ may have been responsible for the lack of $\mathrm{POM}_{\mathrm{R}}$ contribution in SPOM of AG1 and AG2.

As mentioned above, the qualitative aspects of $\mathrm{POM}_{\mathrm{R}}$, particularly related to its degradation, may have affected chemical properties of the tidal flat sedi-

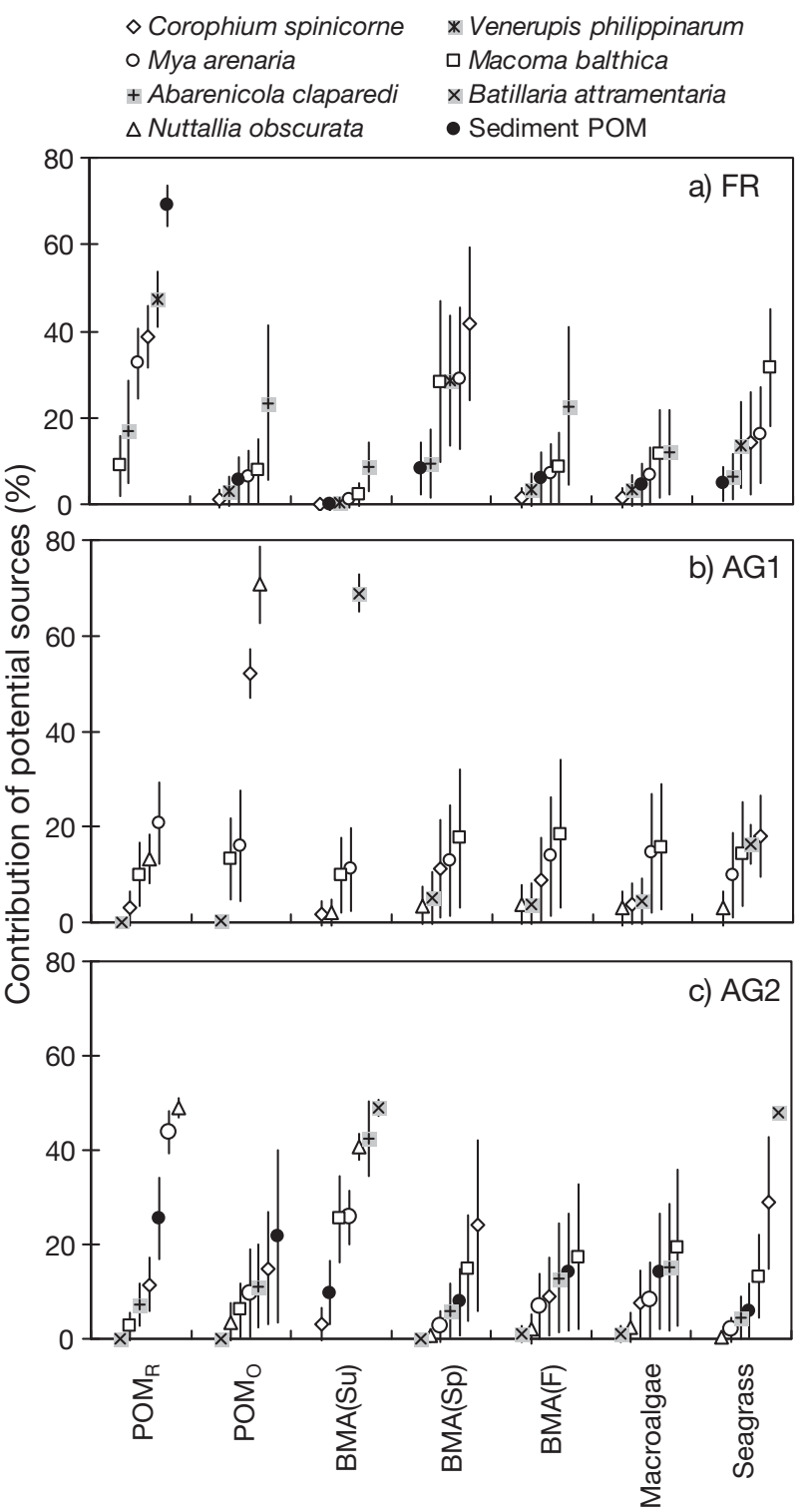

Fig. 5. Percentages of contributions of potential POM sources to SPOM and diets of primary consumer, estimated by IsoSource, in estuaries fed by rivers with (a) FR: mixed forested/urban, and $(\mathrm{b}, \mathrm{c})$ AG1: and AG2: agricultural watersheds. The potential sources considered in this estimation were $\mathrm{POM}_{\mathrm{R}}$ (POM in river water), $\mathrm{POM}_{\mathrm{O}}$ (POM in offshore water), BMA (benthic microalgae in summer, spring and fall), macroalgae Ulva sp. and seagrass Zostera marina 
ments. In AG1 and AG2, however, the coastline configurations of the estuaries are more exposed to the sea compared with that of FR. Such differences in physical environments among the estuaries cause difficulties in drawing conclusions about the importance of $\mathrm{POM}_{R}$ quality on chemical properties of the tidal flat sediments: e.g. the dominance of $\mathrm{POM}_{\mathrm{O}}$ in SPOM might be attributable to large advective transport of $\mathrm{POM}_{\mathrm{O}}$ into those estuaries. Further research is needed for conclusions about the importance of $\mathrm{POM}_{\mathrm{R}}$ quality for its retention in sediments.

\section{Contribution of $\mathrm{POM}_{\mathrm{R}}$ to macrobenthos diets}

The relatively higher $\delta^{15} \mathrm{~N}$ of crabs, snails and polychaetes in comparison with the other macrobenthos groups could be explained by dietary incorporation of not only the summer benthic microalgae with high $\delta^{15} \mathrm{~N}$ but also some other possible sources. The relatively high $\delta^{15} \mathrm{~N}$ of crabs Hemigrapsus oregonensis, and polychaetes Neanthes succinea, Nectoneanthes virens and Hemipodus borealis, may be attributed to their omnivorous or predatory feeding, which potentially increased their $\delta^{15} \mathrm{~N}$ by trophic fractionation (e.g. Minagawa \& Wada 1984). The higher $\delta^{15} \mathrm{~N}$ of depositfeeding primary consumers, i.e. polycaete Abarenicola claparedi and snails, Batillaria attramentaria and Ilyanassa obsoleta, may be due to their assimilation of detritus and/or bacteria that had enriched $\delta^{15} \mathrm{~N}$ (e.g. Kikuchi \& Wada 1996, Caraco et al. 1998, Yokoyama et al. 2005). Microbial mineralisation of detrital POM is known to increase $\delta^{15} \mathrm{~N}$ of the residual POM in sediments (e.g. Owens \& Law 1989, Thornton \& McManus 1994). The stable isotopic fractionation through denitrification also has been shown to increase $\delta^{15} \mathrm{~N}$ of residual nitrate (e.g. Wada \& Hattori 1991, Lehmann et al. 2004). As bacteria on detritus can assimilate nitrogen from ambient water (e.g. Findlay \& Tenore 1982, Caraco et al. 1998), the detritus and/or bacterial consumption may have been responsible for the high $\delta^{15} \mathrm{~N}$ of the deposit-feeding macrobenthos species (for bacterial feeding by the deposit-feeding macrobenthos, see Lopez \& Levinton 1987, Andresen \& Kristensen 2002). In this connection, the high $\delta^{15} \mathrm{~N}$ of benthic microalgae in summer may also be ascribed to their assimilating nitrate fractionated. Since stable isotopic signatures for detritus and bacteria, which are potentially enriched in $\delta^{15} \mathrm{~N}$ through microbial processes, were not taken into account in the mixing model calculation, the accuracy of our estimation of food sources for those deposit-feeding primary consumers involves some uncertainty. However, it is still evident that $\mathrm{POM}_{\mathrm{R}}$ contributed less to the diets of those macrobenthos species in all the estuaries studied, as the stable isotopic signatures for those macrobenthos greatly deviated from those of $\mathrm{POM}_{R}$.

In FR, POM $R$ was estimated to be one of the important food sources for some macrobenthos species despite its relatively low nutritional quality (i.e. high $\mathrm{C}: \mathrm{N}$ ratio). It is possible that the quality of $\mathrm{POM}_{\mathrm{R}}$ in $\mathrm{FR}$ was relatively lower but may still have been sufficiently nutritious for the macrobenthos diets. Meanwhile, Findlay \& Tenore (1982) showed that whereas macrobenthos could assimilate nitrogen directly from refractory, terrestrial-origin, detrital POM, nitrogen from ambient water that was absorbed by bacteria on the POM contributed more to macrobenthos diets. Another experimental study in the tidal flat of FR showed that terrestrial-origin POM (alder leaves) increased its nitrogen content as well as $\delta^{15} \mathrm{~N}$ with time (Sakamaki \& Richardson 2008). Thus, particularly in $\mathrm{FR}$, the contribution of $\mathrm{POM}_{\mathrm{R}}$ to macrobenthos diets may also be due to their indirect assimilation through bacteria growing on the $\mathrm{POM}_{\mathrm{R}}$ (Findlay \& Tenore 1982, Crosby et al. 1990, Caraco et al. 1998). Dominance and long residence time of less degradable $\mathrm{POM}_{R}$ in tidal flat sediments could enhance its contribution to diets of macrobenthos through microbial processes. However, such microbial processes and bacterial feeding by macrobenthos can result in increasing $\delta^{15} \mathrm{~N}$ (e.g. Caraco et al. 1998). This contradicts the relatively low $\delta^{15} \mathrm{~N}$ of macrobenthos that were estimated to be contributed to by $\mathrm{POM}_{\mathrm{R}}$ in FR. The pathway of $\mathrm{POM}_{\mathrm{R}}$ into the diets of macrobenthos in FR needs further examination.

AG1 and AG2 did not show clear evidence for a significant contribution of $\mathrm{POM}_{\mathrm{R}}$ to macrobenthos diets despite the nutritionally high quality of $\mathrm{POM}_{\mathrm{R}}$. The fact that less $\mathrm{POM}_{\mathrm{R}}$ was retained in the tidal flat sediments of those sites suggests that the macrobenthos may not have had a chance to utilise $\mathrm{POM}_{\mathrm{R}}$. The study site where Kasai \& Nakata (2005) found substantial incorporation of $\mathrm{POM}_{\mathrm{R}}$ into the macrobenthos diet received one order of magnitude higher river discharge than our study sites and was located in an upper estuarine area. In addition to the high degradability of $\mathrm{POM}_{\mathrm{R}}$, the physical factors, i.e. the exposed coastline configurations and the small river discharges, may explain the lack of $\mathrm{POM}_{\mathrm{R}}$ contribution to the macrobenthos diets. Our results in AG1 and AG2 suggest that even if $\mathrm{POM}_{R}$ is nutritious, its contribution to macrobenthos diets in estuaries is conditional on the physical environment.

\section{CONCLUSION}

Our results show that $\mathrm{POM}_{\mathrm{R}}$ from the rivers draining the steep, forested watershed was more influential on the estuarine tidal flat compared with that from the 
agricultural watersheds. The lower degradability and longer retention of terrestrial-origin $\mathrm{POM}_{R}$ are expected to be responsible for the contributions of $\mathrm{POM}_{R}$ to the tidal flat SPOM and macrobenthos diets in FR. By contrast, in AG1 and AG2, $\mathrm{POM}_{\mathrm{R}}$, which was assumed to be highly degradable and nutritious, did not dominate SPOM of the tidal flats and also did not show clear evidence of dietary contribution to the tidal flat macrobenthos. The high degradability of $\mathrm{POM}_{R}$ is one possible explanation for the lower contribution to the macrobenthos diets in AG1 and AG2. Our results support that quality of $\mathrm{POM}_{\mathrm{R}}$ is an important factor for $\mathrm{POM}_{\mathrm{R}}$ dynamics and dietary contribution in estuaries and that $\mathrm{C}: \mathrm{N}$ of $\mathrm{POM}_{\mathrm{R}}$, which is usually related to its degradability and residence time, is probably one useful indicator. However, the present study design has only 3 estuarine sites, and the physical environments of those estuaries are not completely standardized, particularly at a large spatial scale. This might have contributed to the differences of $\mathrm{POM}_{R}$ retention in the estuarine tidal flat sediments and also $\mathrm{POM}_{\mathrm{O}}$ import from offshore. Thus, at this stage, we cannot conclusively attribute the difference in $\mathrm{POM}_{\mathrm{R}}$ contributions among the 3 estuaries only to quality of $\mathrm{POM}_{\mathrm{R}}$. In order to make conclusions about the effect of $\mathrm{POM}_{R}$ quality on its dynamics and food web contributions in estuarine tidal flats, further research needs to be conducted considering physical factors, such as river discharge and exposure to the sea.

Acknowledgements. We thank K. Zeron, C. Phelan, T. Lee, D. Leard, N. Hofer, X. Pinto, P. Robinson, J. Schwartzentruber, W. Gibson and G. Harrison for assistance with field and lab work. We thank O. Riche for collecting offshore seawater samples and L. Lu for invertebrate identifications. We also thank A. Lecerf for comments on data analysis. The present study was financially supported by Japan Society for the Promotion of Science and the Natural Sciences and Engineering Research Council of Canada.

\section{LITERATURE CITED}

Akiyama A (1988) Benthic animals in an intertidal flat. In: Kurihara Y (ed) Ecology and ecotechnology in estuarinecoastal area. Tokai University Press, Tokyo, p 85-98 (in Japanese)

Andresen M, Kristensen E (2002) The importance of bacteria and microalgae in the diet of the deposit-feeding polychaete Arenicola marina. Ophelia 56:179-196

Behrens Yamada S, Boulding EG (1998) Claw morphology, prey size selection and foraging efficiency in generalist and specialist shell-breaking crabs. J Exp Mar Biol Ecol 220:191-211

Bottom DL, Jones KK, Cornwell TJ, Gray A, Simenstad CA (2005) Patterns of Chinook salmon migration and residency in the Salmon River estuary (Oregon). Estuar Coast Shelf Sci 64:79-93

> Bowen SH, Lutz EV, Ahlgren MO (1995) Dietary protein and energy as determinants of food quality: trophic strategies compared. Ecology 76:899-907

Caraco NF, Lampman G, Cole JJ, Limburg KE, Pace ML, Fischer D (1998) Microbial assimilation of DIN in a nitrogen-rich estuary: implications for food quality and isotope studies. Mar Ecol Prog Ser 167:59-71

Caron A, Desrosiers G, Olive PJW, Retière C, Nozais C (2004) Comparison of diet and feeding activity of two polychaetes, Nephtys caeca (Fabricius) and Nereis virens (Sars), in an esturine intertidal environment in Québec, Canada. J Exp Mar Biol Ecol 304:225-242

Chanton J, Lewis FG (2002) Examination of coupling between primary and secondary production in a river-dominated estuary: Apalachicola Bay, Florida, USA. Limnol Oceanogr 47:683-697

Commito JA, Ambrose WG Jr (1985) Multiple trophic levels in soft-bottom communities. Mar Ecol Prog Ser 26:289-293

Costanza R, d'Arge R, de Groot R, Farber S, Grasso M, Hannon B, and others (1997) The value of the world's ecosystem services and natural capital. Nature 387:253-260

Crosby MP, Newell RIE, Langdon CJ (1990) Bacterial mediation in the utilization of carbon and nitrogen from detrital complexes by Crassostrea virginica. Limnol Oceanogr 35: 625-639

Darnaude AM (2005) Fish ecology and terrestrial carbon use in coastal areas: implications for marine fish production. J Anim Ecol 74:864-876

> DeNiro MJ, Epstein S (1978) Influence of diet on the distribution of carbon isotopes in animals. Geochim Cosmochim Acta 42:495-506

> Ehrenhauss S, Witte U, Bühring SI, Huettel M (2004) Effect of advective pore water transport on distribution and degradation of diatoms in permeable North Sea sediments. Mar Ecol Prog Ser 271:99-111

Enríquez S, Duarte CM, Sand-Jensen K (1993) Patterns in decomposition rates among photosynthetic organisms: the importance of detritus C:N:P content. Oecologia 94: $457-471$

Findlay S, Tenore K (1982) Nitrogen source for a detritivore: detritus substrate versus associated microbes. Science 218:371-373

Forster S, Zettler ML (2004) The capacity of the filter-feeding bivalve Mya arenaria L. to affect water transport in sandy beds. Mar Biol 144:1183-1189

Hymel SN, Plante CJ (2000) Feeding and bacteriolytic responses of the deposit-feeder Abarenicola pacifica (Polychaeta: Arenicolidae) to changes in temperature and sediment food concentration. Mar Biol 136:1019-1027

> Johnson LB, Richards C, Host GE, Arthur JW (1997) Landscape influences on water chemistry in Midwestern stream ecosystems. Freshw Biol 37:193-208

Kang CK, Kim JB, Lee KS, Kim JB, Lee PY, Hong JS (2003) Trophic importance of benthic microalgae to macrozoobenthos in coastal bay system in Korea: dual stable C and N isotope analysis. Mar Ecol Prog Ser 259:79-92

Kasai A, Nakata A (2005) Utilization of terrestrial organic matter by the bivalve Corbicula japonica estimated from stable isotope analysis. Fish Sci 71:151-158

Kasai A, Horie H, Sakamoto W (2004) Selection of food sources by Ruditapes philippinarum and Mactra veneriformis (Bivalva: Mollusca) determined from stable isotope analysis. Fish Sci 70:11-20

Kelaher BP, Levinton JS, Hoch JM (2003) Foraging by the mud snail Ilyanassa obsoleta (Say) modulates spatial variation in benthic community structure. J Exp Mar Biol Ecol 292:139-157

Kiffney PM, Richardson JS, Bull JP (2003) Responses of periphyton and insects to experimental manipulation of ripar- 
ian buffer width along forest streams. J Appl Ecol 40: 1060-1076

Kikuchi E, Wada E (1996) Carbon and nitrogen stable isotopes of deposit-feeding polychaetes in the Nanakita River Estuary, Japan. Hydrobiologia 321:69-75

Lee SY (2000) Carbon dynamics of Deep Bay, eastern Pearl River estuary, China. II: trophic relationship based on carbon- and nitrogen-stable isotopes. Mar Ecol Prog Ser 205:1-10

Lehmann MF, Bernasconi SM, McKenzie JA, Barbieri A, Simona M, Veronesi M (2004) Seasonal variation of the $\delta^{13} \mathrm{C}$ and $\delta^{15} \mathrm{~N}$ of particulate and dissolved carbon and nitrogen in Lake Lugano: constraints on biogeochemical cycling in a eutrophic lake. Limnol Oceanogr 49:415-429

Levings CD, Colin K, Raymond B (1991) Intertidal habitats used by juvenile chinook salmon Oncorhynchus tshawytscha rearing in the North Arm of the Fraser River estuary. Mar Pollut Bull 22:20-26

Lopez GR, Levinton JS (1987) Ecology of deposit-feeding animals in marine sediments. Q Rev Biol 62:235-260

Lorenzen CJ (1967) Determination of chlorophyll and pheo-pigments: spectrophotometric equations. Limnol Oceanogr 12:343-346

Martinetto P, Teichberg M, Valiela I (2006) Coupling of estuarine benthic and pelagic food webs to land-derived nitrogen sources in Waquoit Bay, Massachusetts, USA. Mar Ecol Prog Ser 307:37-48

Middleburg JJ, Barranguet C, Boschker HTS, Herman PMJ, Moens T, Heip CHR (2000) The fate of intertidal microphytobenthos carbon: an in situ ${ }^{13} \mathrm{C}$-labeling study. Limnol Oceanogr 45:1224-1234

Minagawa M, Wada E (1984) Stepwise enrichment of ${ }^{15} \mathrm{~N}$ along food chains: further evidence and the relation between $\delta^{15} \mathrm{~N}$ and animal age. Geochim Cosmochim Acta 48:1135-1140

Nakamura Y (2001) Filtration rates of the Manila clam Ruditapes philippinarum: dependence on prey items including bacteria and picocyanobacteria. J Exp Mar Biol Ecol 266:181-192

Noe GB, Hupp CR (2005) Carbon, nitrogen and phosphorus accumulation in floodplains of Atlantic coastal plain rivers, USA. Ecol Appl 15:1178-1190

Ogrinc N, Fontolan G, Faganeli J, Covelli S (2005) Carbon and nitrogen isotope compositions of organic matter in coastal marine sediments (the Gulf of Trieste, N Adriatic Sea): indicators of sources and preservation. Mar Chem 95:163-181

Otero E, Culp R, Noakes JE, Hodson R (2000) Allocation of particulate organic carbon from different source in two contrasting estuaries of southern USA. Limnol Oceanogr 45:1753-1763

Owens NJP, Law CS (1989) Natural variations in ${ }^{15} \mathrm{~N}$ content of riverine and estuarine sediments. Estuar Coast Shelf Sci 28:407-416

Pardo EV, Dauer DM (2003) Particle size selection in individuals from epifaunal versus infaunal populations of the

Editorial responsibility: Matthias Seaman,

Oldendorf/Luhe, Germany nereidid polychaete Neanthes succinea (Polychaeta: Nereididae). Hydrobiologia 496:355-360

Peterson CH, Skilleter GA (1994) Control of foraging behavior of individuals within an ecosystem context: the clam Macoma bolthica, flow environment and siphon-cropping fishes. Oecologia 100:256-267

Phillips DL, Gregg JW (2003) Source partitioning using stable isotopes: coping with too many sources. Oecologia 136: 261-269

Riera P, Richard P (1996) Isotopic determination of food source of Crassostea gigas along a trophic gradient in the estuarine bay of Marennes-Oleron. Estuar Coast Shelf Sci 42:347-360

Riisgård HU, Kamermans P (2001) Switching between deposit and suspension feeding in coastal zoobenthos. In: Reise K (ed) Ecological studies, ecological comparisons of sedimentary shores. Springer, Berlin, p 73-101

$>$ Roy AH, Faust CL, Freeman MC, Meyer JL (2005) Reachscale effects of riparian forest cover on urban stream ecosystems. Can J Fish Aquat Sci 62:2312-2329

Sakamaki T, Richardson JS (2008) Retention, breakdown and biological utilisation of deciduous tree leaves in an estuarine tidal flat of southwestern British Columbia, Canada. Can J Fish Aquat Sci 65:38-46

Tenore KR (1977) Growth of Capitella capitata cultured on various levels of detritus derived from difference sources. Limnol Oceanogr 22:936-941

Tenore KR, Hanson RB (1980) Availability of detritus of different types and ages to a polychaete macroconsumer Capitella capitata. Limnol Oceanogr 25:553-558

- Thornton SF, McManus J (1994) Application of organic carbon and nitrogen stable isotope and $\mathrm{C}: \mathrm{N}$ ratio as source indicator of organic matter provenance in estuarine systems: evidence from the Tay Estuary, Scotland. Estuar Coast Shelf Sci 38:219-233

Thorpe JE (1994) Salmonid fishes and the estuarine environment. Estuaries 17:76-93

Wada E, Hattori A (1991) Nitrogen in the sea: forms, abundances, and rate processes. CRC Press, Boca Raton, FL

Webster JR, Waide JB (1982) Effects of forest clear-cutting on leaf breakdown in a southern Appalachian stream. Freshw Biol 12:331-344

Whitlatch RB, Obrebski S (1980) Feeding selectivity and coexistence in two deposit-feeding gastropods. Mar Biol 58:219-225

Wipfli MS, Richardson JS, Naiman RJ (2007) Ecological linkages between headwaters and downstream ecosystems: transport of organic matter, invertebrates and wood down headwater channels. J Am Water Resour Assoc 43:1-14

Yokoyama H, Ishihi Y (2003) Feeding of the bivalve Theora lubrica on benthic microalgae: isotopic evidence. Mar Ecol Prog Ser 255:303-309

Yokoyama H, Tamaki A, Koyama K, Ishihi Y, Shimada K, Harada K (2005) Isotopic evidence for phytoplankton as a major food source for macrobenthos on an intertidal sandflat in Ariake Sound, Japan. Mar Ecol Prog Ser 304:101-116

Submitted: July 6, 2007; Accepted: December 20, 2007

Proofs received from author(s): May 8, 2008 